\title{
Effect of Metakaolin and Condensed Silica Fume on the Rheological and Structural Properties of Self-compacting Concrete
}

\author{
S. Vijaya Kumar ${ }^{1, *}$, B. Dean Kumar*, B L P Swami ${ }^{3}$ \\ ${ }^{1}$ Department of Civil Engineering, Vasavi College of Engineering, Hyderabad, India \\ ${ }^{2}$ Department of Civil Engineering, Jawaharlal Nehru Technological University, Hyderabad, India \\ ${ }^{3}$ Department of Civil Engineering, Methodist College of Engineering and Technology, Hyderabad, India
}

Received August 15, 2020; Revised September 23, 2020; Accepted October 19, 2020

\section{Cite This Paper in the following Citation Styles}

(a): [1] S.Vijaya Kumar, B.Dean Kumar, B L P Swami, "Effect of Metakaolin and Condensed Silica Fume on the Rheological and Structural Properties of Self-compacting Concrete," Civil Engineering and Architecture, Vol. 8, No. 5, pp. 1057 - 1062, 2020. DOI: 10.13189/cea.2020.080532.

(b): S.Vijaya Kumar, B.Dean Kumar, B L P Swami (2020). Effect of Metakaolin and Condensed Silica Fume on the Rheological and Structural Properties of Self-compacting Concrete. Civil Engineering and Architecture, 8(5), 1057 1062. DOI: $10.13189 /$ cea.2020.080532.

Copyright $\mathrm{C} 2020$ by authors, all rights reserved. Authors agree that this article remains permanently open access under the terms of the Creative Commons Attribution License 4.0 International License

\begin{abstract}
This article deals with the comparison between the metakaolin and condensed silica fume contributions in the flyash based self-compacting concrete (SCC). Self-compacting concrete with mineral admixtures like flyash and condensed silica fume is prepared by cement replacing partially at 20 and 10 percentages respectively. M40 grade of the concrete was designed by adjusting the ratio of the fine aggregate to the total aggregate volume to fulfill the requirements of the SCC. Another M40 grade of SCC is designed with the flyash and metakaolin as the mineral admixtures with the same percentage of replacement for cement by mass. Rheological properties are examined as per EFNARC specifications for flowability; passing ability and segregation resistance for both the triple blended self-compacting concretes (TBSCC). For getting the required flowability of concrete and for modifying the viscous nature of the concrete, superplasticizer and viscosity modifying agents are additionally added to the concrete. The structural properties like compression and split tensile strengths of the specimens are recorded by conducting the standard tests. By comparing the strength results, it is concluded that metakaolin and silica fume have only marginal changes between them in the rheological as well as the mechanical properties of the triple blended self-compacting concrete.
\end{abstract}

Keywords Self-compacting Concrete, Triple Blended, Metakaolin, Condensed Silica Fume, Flyash, Rheology of the Concrete, Structural Properties, Superplasticizer, Viscosity Modifying Agent (VMA)

\section{Introduction}

Compaction of the concrete has a very significant role in obtaining the required strength of the concrete. But in the fabrication of thin concrete structural elements, the compaction is too difficult, and also for placing the fresh concrete in the dense reinforcement zones. To overcome these difficulties, in the late 90's Okamura, Ochi and Ozawa have introduced the self-compacting concrete technique. With this, the concrete fills all the places of the formwork by its weight and there is no need for the compaction for becoming dense. The self-compacting concrete can be placed either by pouring or pumping, depending upon the structural elements like slab, beam, and column. Due to the addition or replacement of mineral admixtures such as flyash, condensed silica fume, and metakaolin the workability property of the concrete is influenced and also enhances the structural properties like compression, tensile and flexural strengths. The chemical 
admixture like superplasticizer (SP) improves the flowability of the concrete. The viscosity of the fresh concrete is modified by incorporating the viscosity modifying agent (VMA) along with SP.

Masahiro Ouchi [1] studied the influence of the superplasticizer on the properties of the self-compacting concrete. In this article, the authors concluded that the dosage of the superplasticizer on the volume of the concrete will affect the rheological properties, and an optimum dosage is evolved. Cyr. M, Mouret [2] did the experimental investigation on the rheological characterization of super plasticized cement pastes containing mineral admixtures, and the consequences on self-compacting concrete. There was improvement reported in the flowability of concrete. Brouwers, H, Radix, $\mathrm{H}$ [3] studied the experimental way of obtaining self-compacting concrete and a theoretical approach was also given by the authors. P. Dinakar and S. N. Manu [4] gave the mix design for high strength self-compacting concrete using metakaolin as one of the mineral admixtures. Siddique, R [5] investigated the contribution of class F flyash on the properties of the self-compacting concrete. Corinaldesi, V, Moriconi, G [6] investigated the characterization of self-compacting concrete prepared with different fibers and mineral admixtures. Siddique, R [7] examined the coal flyash and the bottom ash contributions on the strength properties of self-compacting concrete, and the authors also studied the water to cement ratio's effect on the fresh and hardened properties of SCC. Assem Hassan and Mohammed lakherim [8] studied the effect of metakaolin and silica fume on the rheology of the self-compacting concrete. Vikassrivastava, Rakesh Khanna [9] examined the effect of silica fume and metakaolin on the structural properties of the concrete. Ramanathan, P [10] conducted the tests on the performance of self-compacting concrete containing different mineral admixtures, and conclusions are drawn from the experimentation giving that mineral admixtures play a major role on the strength of the SCC. Ioannis P. Sfikas [11] did the experimental investigation on the rheology and mechanical properties of the self-compacting concrete containing metakaolin and presented improved results. Hafez E. Elyamany [12] studied the effect of the filler type of material on the physical, mechanical, and microstructural properties of the self-compacting concrete. Akinpelu, MA [13] did the experimental work for the evaluation of the relation between splitting tensile strength and the compressive strength of self-compacting concrete. EFNARC-2005(The European Federation of National Associations Representing for Concrete-Specifications for the self-compacting concrete) [14] gave the detailed specifications for SCC. The details of various tests to be conducted for the flowability of SCC were also given. ACI (American Concrete Institute)237R-07-2007[15] gave the various recommendations on the preparation, flowability, and tests for SCC. The objective of this research article is comparison between the admixtures which will contributed rheological and structural properties of the SCC.

\section{Material and Mix Design}

\subsection{Material Used}

\subsubsection{Cement}

53 grade of Ordinary Portland Cement (OPC) confirming to IS:10269-2015 [16] is used as binding material. The specific surface area of this cement is around $2800 \mathrm{~cm}^{2} /$ gram, specific gravity is 3.15 , and the consistency of the cement is $32 \%$. All these physical properties of the $\mathrm{OPC}$ are satisfied by the sample.

\subsubsection{Fine Aggregate}

River sand is used as a fine aggregate in this experimentation. The fineness modulus of this sand is determined and recorded as 2.82. Depending upon the percentage of passing in the various sizes of the sieves, it is confirmed that this fine aggregate is confirming to Zone II. The specific gravity of this material is 2.64 . These are fulfilling the provisions of IS:383-2016 [17].

\subsubsection{Coarse Aggregate}

As per specification of the code of practice for the coarse aggregate IS:383-2016[17], the physical properties of these materials such as specific gravity, bulk density, and fineness modulus are recorded as $2.64,1610 \mathrm{~kg} / \mathrm{m}^{3}$, and 6.78 respectively.

\subsection{Mineral Admixtures}

\subsubsection{Flyash (FA)}

In this experimentation, the $\mathrm{F}$ type flyash was used as the main supplementary cementitious material (SCM). It is obtained from the Ramagundam thermal power plant in Andhra Pradesh, India. The specific surface area of the flyash is recorded as $4750 \mathrm{~cm}^{2} / \mathrm{gm}$ by conducting Blaine's permeability test. The cement can be replaced by this type of flyash ranging from $15 \%$ to $25 \%$ by mass of the cement. The optimum percentage may vary depending upon the application. In this work, $20 \%$ of this mineral admixture is used as SCM.

\subsubsection{Condensed silica fume (SF)}

Condensed silica fume consists mainly of silica in non-crystalline form and contains a large percentage of active silicon dioxide $\left(\mathrm{SiO}_{2}\right)$. This admixture is used to replace OPC by $9-15 \%$. In this work, $10 \%$ of CSF is used as a replacement of cement because of its high specific surface area which is around $15000 \mathrm{~cm}^{2} /$ gram.

\subsubsection{Metakaolin (MK)}


Metakaolin is the most effective pozzolanic material for use as partial replacement to OPC because it has more compatible properties with the cement. It is a by-product and is formed by calcination of clay. It may be used to replace cement at ranges of $5-10 \%$ by weight of the cement. In this experimentation, $10 \%$ of Metakaoline is used for the replacement of cement.

The physical and chemical properties of all these mineral admixtures are shown in tables 1 and 2. The mineral admixtures were used at optimum percentages as a replacement to OPC. In this experimentation, mineral admixtures are added in one set of concrete as $10 \% \mathrm{CSF}$, and $20 \% \mathrm{FA}$, and in another set of concrete as $10 \% \mathrm{MK}$, and $20 \%$ FA.

\subsection{Chemical Admixtures}

A high-performance superplasticizer based on polycarboxylic ether (PCE) is used in this experimentation as a superplasticizer(SP). It is commercially available as Glenium B233. In addition to this, VMA (Viscosity Modifying Agent) is also used to minimize the tendency of the highly fluid mix to segregate. Commercially it is available as Glenium-2. These chemicals are supplied by M/s BASF INDIA LTD.

\subsection{Mix Design}

Based on physical properties like specific gravity, fineness modulus, and other values, the M40 grade of normal concrete(NC) is designed as per IS 10262-2009[19] specification. The proportion of the materials shown in table 3. The mix design for SCC can be obtained by rearranging the fine aggregate to the total aggregate volume ratio between 0.54 to 0.68 . After so many trials, the following mix for SCC is adopted which is fulfilling the primary requirements like flowability, passing ability, and segregation resistance as per EFNARC [14]. Final proportions of the materials are given in table 4.

Table 1. Physical properties of admixtures

\begin{tabular}{|c|c|c|c|c|}
\hline S no & Properties & Flyash & $\begin{array}{c}\text { Condensed } \\
\text { silica fume }\end{array}$ & $\begin{array}{c}\text { Meta- } \\
\text { kaolin }\end{array}$ \\
\hline 1 & $\begin{array}{c}\text { Specific } \\
\text { Gravity }\end{array}$ & 2.30 & 2.20 & 2.50 \\
\hline 2 & $\begin{array}{c}\text { Specific } \\
\text { Surface Area } \\
\left(\mathrm{cm}^{2} / \text { gram }\right)\end{array}$ & $\begin{array}{c}3500- \\
3800\end{array}$ & $\begin{array}{c}150000 \\
200000\end{array}$ & $7000-9000$ \\
\hline 3 & Colour & Grey & Dark grey & white \\
\hline 4 & Structure & $\begin{array}{c}\text { Mostly } \\
\text { globular }\end{array}$ & $\begin{array}{c}\text { Non- } \\
\text { crystalline }\end{array}$ & $\begin{array}{c}\text { Non- } \\
\text { crystalline }\end{array}$ \\
\hline
\end{tabular}

Table 2. Chemical composition of various mineral admixtures (percentages) ${ }^{* *}$

\begin{tabular}{|c|c|c|c|c|}
\hline $\begin{array}{c}\mathrm{S} \\
\text { no }\end{array}$ & Oxides & Flyash & $\begin{array}{c}\text { Condensed } \\
\text { silica fume }\end{array}$ & Metakaolin \\
\hline 1 & $\begin{array}{c}\text { Silicon di oxide } \\
\mathrm{SiO}_{2}\end{array}$ & 55 & 90 & 52 \\
\hline 2 & $\begin{array}{c}\text { Aluminum oxide } \\
\mathrm{Al}_{2} \mathrm{O}_{3}\end{array}$ & $20-70$ & 1 & 40 \\
\hline 3 & Ferric Oxide $\mathrm{Fe}_{2} \mathrm{O}_{3}$ & $10-15$ & 0.03 & 1.20 \\
\hline 4 & $\begin{array}{c}\text { Calcium Oxide } \\
\text { Cao }\end{array}$ & 1.63 & 0.10 & 2.0 \\
\hline 5 & Magnesium oxides & 3.96 & 0.20 & 0.65 \\
\hline 6 & Sulfur trioxide $\mathrm{SO}_{3}$ & 0.65 & 23 & 0.00 \\
\hline
\end{tabular}

**The above data is collected from ACI international seminar on High volume Flyash and Blended concrete - 2001[18].

Table 3. M40 grade mix as per IS 10262-2009[19] for NCC (Normal Cement Concrete)

\begin{tabular}{|c|c|c|c|}
\hline Cement & Fine Aggregate & Coarse Aggregate & W/C \\
\hline 1 & 1.38 & 2.4 & 0.45 \\
\hline
\end{tabular}

Table 4. M40 grade mix as per EFNARC[14] for SCC (Self-Compacting concrete)

\begin{tabular}{|c|c|c|c|}
\hline cement & Fine Aggregate & Coarse Aggregate & W/C \\
\hline 1 & 2.33 & 1.37 & 0.45 \\
\hline
\end{tabular}

Table 5. Mix Identification

\begin{tabular}{|c|c|}
\hline Mix for M40 grade of SCC & Abbreviation \\
\hline M1-SF $\mathrm{MK}_{0} \mathrm{FA}_{0}$ & $\begin{array}{c}\text { Mix1 with } 0 \% \text { of condensed silica } \\
\text { fume, } 0 \% \text { of metakaolin, } 0 \% \text { flyash }\end{array}$ \\
\hline $\mathrm{M} 2-\mathrm{SF}_{0} \mathrm{MK}_{0} \mathrm{FA}_{30}$ & $\begin{array}{c}\text { Mix2 with } 0 \% \text { of condensed silica } \\
\text { fume, } 0 \% \text { of metakaolin, } 30 \% \text { flyash }\end{array}$ \\
\hline $\mathrm{M} 3-\mathrm{SF}_{0} \mathrm{MK}_{10} \mathrm{FA}_{20}$ & $\begin{array}{c}\text { Mix3 with } 0 \% \text { of condensed silica } \\
\text { fume, } 10 \% \text { of metakaolin, } 20 \% \text { flyash }\end{array}$ \\
\hline $\mathrm{M} 4-\mathrm{SF}_{10} \mathrm{MK}_{0} \mathrm{FA}_{20}$ & $\begin{array}{c}\text { Mix } 4 \text { with } 10 \% \text { of condensed silica } \\
\text { fume, } 0 \% \text { of metakaolin, } 20 \% \text { flyash }\end{array}$ \\
\hline
\end{tabular}

Here cement is blended with mineral admixtures like flyash, condensed silica fume, and metakaolin for a total of $30 \%$ replacement to cement. For one set of concrete, it is $30 \%$ replacement of flyash alone, for remaining two sets of the concrete flyash is blended with condensed silica fume and metakaolin.

\subsection{Properties of the Fresh Self-compacting Concrete (Rheological properties)}

The rheological properties of the fresh concrete are flowability, passing ability, and segregation resistance which are determined by slump cone test, V-funnel test, and L-box test respectively. The mixed abbreviations, the quantities of materials, and rheological test results are shown in tables 5,6 , and 7 . 
Table 6. Quantity of Materials per $\mathrm{M}^{3}$ of Concrete (M40), with Admixtures

\begin{tabular}{|c|c|c|c|c|c|c|c|c|c|}
\hline Mix & $\begin{array}{c}\text { Cement } \\
(\mathrm{Kg})\end{array}$ & $\begin{array}{c}\text { Fine } \\
\text { aggregate } \\
(\mathrm{Kg})\end{array}$ & $\begin{array}{c}\text { Coarse } \\
\text { aggregate } \\
(\mathrm{Kg})\end{array}$ & $\begin{array}{c}\text { Condensed } \\
\text { silica fume } \\
(\mathrm{Kg})\end{array}$ & $\begin{array}{l}\text { Metakaolin } \\
(\mathrm{Kg})\end{array}$ & $\begin{array}{c}\text { Flyash } \\
(\mathrm{Kg})\end{array}$ & $\begin{array}{c}\text { Superplasticizer } \\
\text { (SP) } \\
\text { Percentage of } \\
\text { concrete }\end{array}$ & $\begin{array}{c}\text { Viscosity } \\
\text { modifying } \\
\text { agent (VMA) } \\
\text { Percentage of } \\
\text { concrete }\end{array}$ & $\begin{array}{l}\text { Water } \\
\text { (liter) }\end{array}$ \\
\hline M1 & 455 & 1065 & 625 & 0 & 0 & 0 & 1 & 0.1 & 205 \\
\hline M2 & 318 & 1065 & 625 & 0 & 0 & 136 & 1 & 0.1 & 205 \\
\hline M3 & 318 & 1065 & 625 & 0 & 46 & 91 & 1 & 0.1 & 205 \\
\hline M4 & 318 & 1065 & 625 & 46 & 0 & 91 & 1 & 0.1 & 205 \\
\hline
\end{tabular}

Table 7. Rheological properties of the Tri-blended Self Compacting Concrete. (TBSCC)

\begin{tabular}{|c|c|c|c|c|}
\hline Mix & Slump flow in $\mathrm{mm}$ & V funnel in seconds & $\begin{array}{c}\text { L- box in the ratio } \\
\mathrm{H} 2 / \mathrm{H} 1^{*}\end{array}$ & Remarks \\
\hline $\mathrm{M} 1-\mathrm{SF}_{00} \mathrm{MK}_{00} \mathrm{FA}_{00}$ & 610 & 9 & 0.88 & \multirow{4}{*}{$\begin{array}{l}\text { *H2-height of concrete } \\
\text { in vertical } \\
\text { limb,H1-height of } \\
\text { concrete in horizontal } \\
\text { limb }\end{array}$} \\
\hline $\mathrm{M} 2-\mathrm{SF}_{00} \mathrm{MK}_{00} \mathrm{FA}_{30}$ & 630 & 7 & 0.90 & \\
\hline $\mathrm{M} 3-\mathrm{SF}_{0} \mathrm{MK}_{10} \mathrm{FA}_{20}$ & 650 & 6.5 & 0.91 & \\
\hline $\mathrm{M} 4-\mathrm{SF}_{10} \mathrm{MK}_{0} \mathrm{FA}_{20}$ & 680 & 5 & 0.92 & \\
\hline
\end{tabular}

\section{Results and Discussions}

It is observed that the rheological properties of these triple blended self-compacting concrete (Table 7) are found to be as per the norms of the EFNARC (14) specifications. In the SCC mix mentioned in table 4, it is observed that the mineral admixtures have influenced the primary properties of the SCC like passing, free-flowing, and no segregation. For all the mixes mentioned in table 5, along with the mineral admixtures, superplasticizer and viscosity modifying agents were added up to 1.0 and 0.1 percentages by weight of the cement respectively. It is indicated (table) that SCC with flyash and condensed silica fume as mineral admixtures which replaced cement at 20,10 percentages respectively by mass (M4) have better rheological properties, compared to the other combination of the admixtures at the same percentages. Because the C-S-H gel bond is more in this combination of the mix.

\subsection{Mechanical Properties of the Mixes}

For determination of the structural properties of these triple blended self-compacting concrete, standard cubes, and cylinders were cast as per the specifications of the Indian standard code. The curing period for these samples is 28 days. The basic strengths are evaluated by conducting the compressive, and the split tensile tests as per IS-516[20].

\subsection{The Compressive Strength}

For obtaining the getting the compressive strength results, a total of 36 standard cubes of size $150 \mathrm{~mm} \mathrm{x}$ $150 \mathrm{~mm} \times 150 \mathrm{~mm}$ were cast for four combinations of the mixes (Table 7). These samples were tested at 3 days, 14 days, and 28 days. The variation of these strengths is plotted in fig 1 . The best mix for getting more compressive strength of SCC is $10 \%$ condensed silica fume with a $20 \%$ flyash (M4-SF $10 \mathrm{MK}_{0} \mathrm{FA}_{20}$ ). From these results, it can be seen that Mix-M4 (20\% flyash and 10\% condensed silica fume) has 28 days strength which is marginally more compared to the same grade of Mix with $20 \%$ flyash and $10 \%$ metakaolin. $\left(\mathrm{M} 3-\mathrm{SF}_{0} \mathrm{MK}_{10} \mathrm{FA}_{20}\right)$

The best-fit log curve for this compressive strength is arrived as,

$$
f_{c c}=29.415 \ln (t)+16.049 \text {, }
$$

Where, $\mathbf{f}_{\text {cc }}$ compressive strength in $\mathrm{MPa}\left(\mathrm{N} / \mathrm{mm}^{2}\right)$, for M4 mix and, $t$ is the age of the concrete sample in days. 


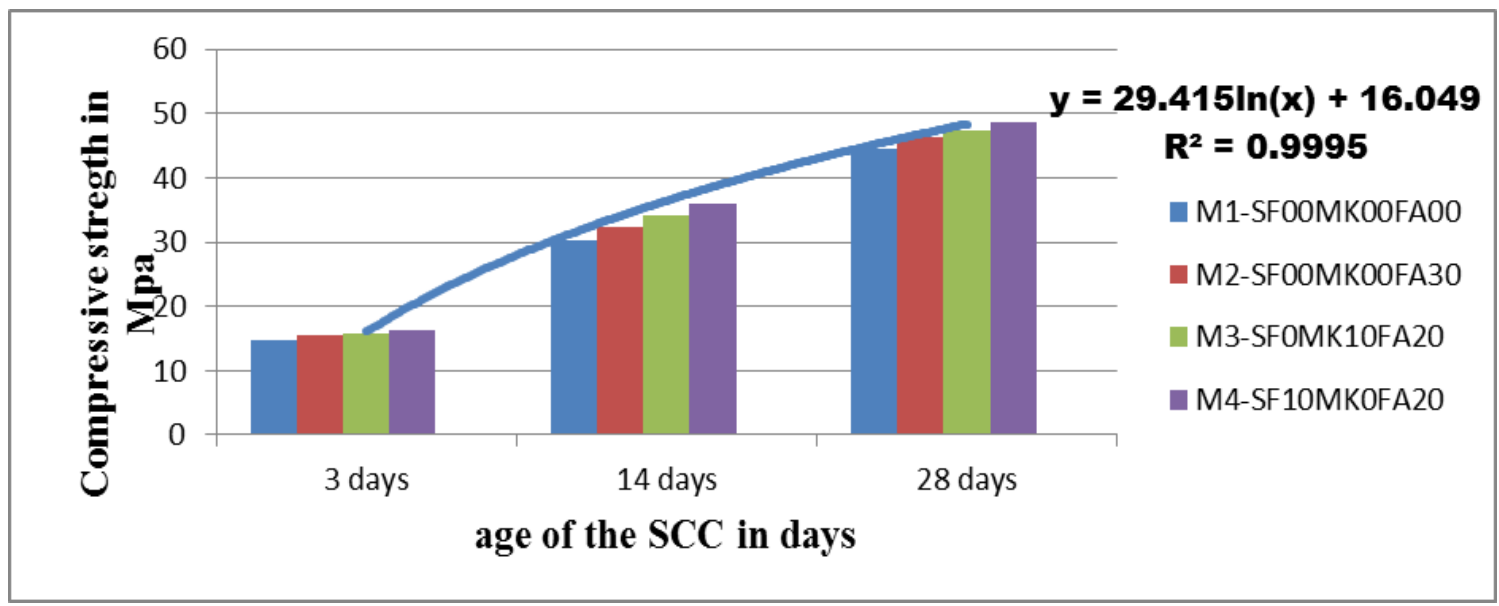

Figure 1. Variation of the compressive strength of SCC with different percentages of the admixtures

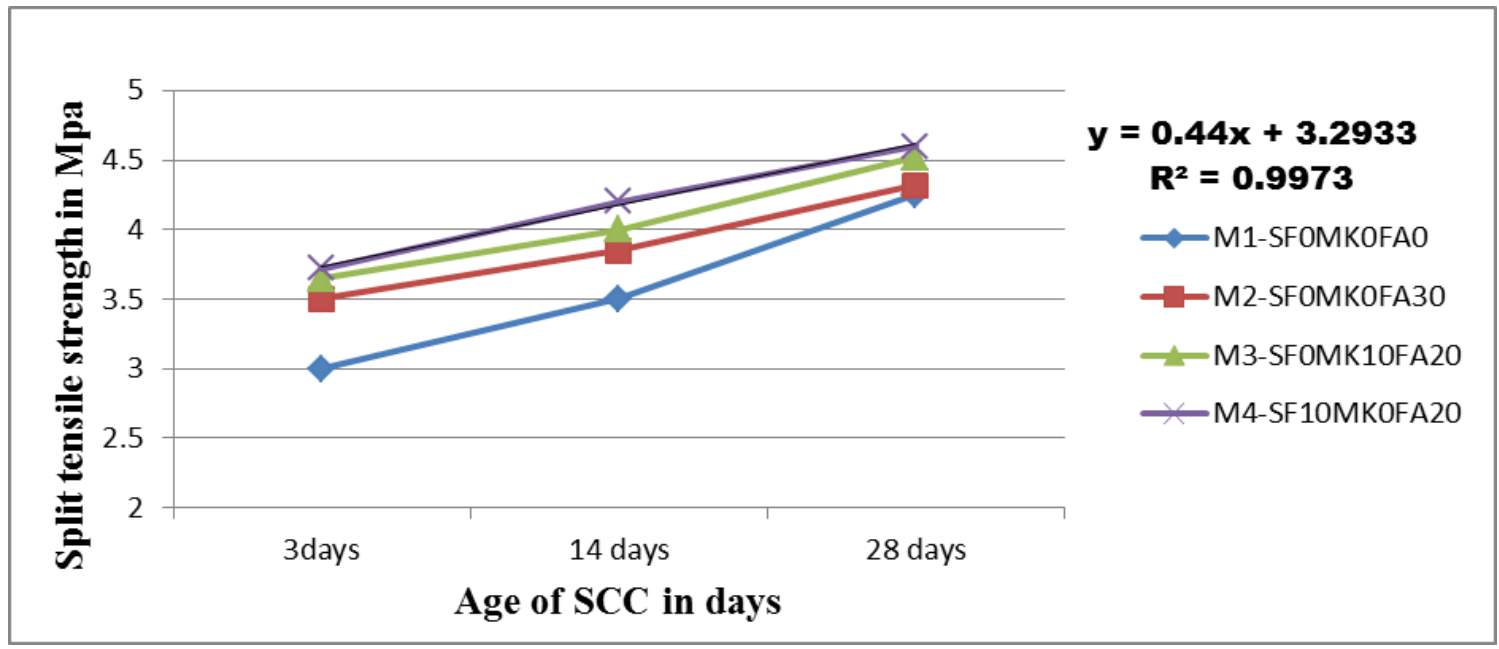

Figure 2. Variation of the Split tensile strength of SCC with different percentages of the admixtures

\subsection{The Split Tensile Strength}

For the above 4 combinations of the concrete mixes, a total of 36 number of standard cylinders of size $150 \mathrm{~mm}$ diameter and $300 \mathrm{~mm}$ height were cast. These samples were cured for 3 days, 14 days, and 28 days in potable water. The final test results are plotted in fig 2. The better mix (M4) with $10 \%$ condensed silica fume and $20 \%$ flyash has shown the highest split tensile strength. Mix-M4 which has $20 \%$ flyash and $10 \%$ condensed silica fume has 28 days split tensile strength more than the same grade of Mix-M3, with a $20 \%$ flyash and $10 \%$ metakaolin. The best fit linear curve for this strength is given by $\mathbf{F}_{\mathrm{ct}}=\mathbf{0 . 4 4} \mathbf{t}+\mathbf{3 . 2 9 3 3}$, where

$\mathbf{F}_{\mathrm{ct}}$ - The split tensile strength in $\mathrm{MPa}\left(\mathrm{N} / \mathrm{mm}^{2}\right)$ for $\mathrm{M} 4, \mathrm{t}$ is the age of the concrete sample in days.

\section{Conclusions}

The concluding remarks on the present experimental investigations are given as follows.
1) Mineral Admixtures like flyash, silica fume, metakaolin etc contribute towards better flowability of the concrete. The condensed silica fume because of its high specific surface area(fineness) has given better flowability compared to metakaolin. Hence, the combinations of flyash with silica fume has given better flowability compared to the combination of flyash with metakaolin.

2) Chemical admixtures like super plasticizer and viscosity modifying agents are necessary to maintain the rheological properties of SCC. They influence the strength and durability properties to certain extent.

3) Due to the combination of flyash and metakaolin there is some increase in the strength properties of SCC. The strength increase due to the combination of flyash and silica fume is more than the former because of higher fineness of silica fume.

4) The silicate content in the condensed silica fume is much more than the other admixtures and this causes more C-S-H gel formation and it results in more flowability without segregation. 
5) The flow of the SCC which has condensed silica fume as one of the admixtures is 12 percent more compared to the basic SCC without mineral admixture. The flow of the SCC with metakaolin is only $6 \%$ higher compared to the basic. This has been established as a result of workability test conducted on SCC.

6) The structural properties of the tri-blended SCC have shown that $10 \% \mathrm{CSF}$ and $20 \%$ flyash combination has given optimum values of compressive strength, and the split tensile strength. These values are around $10 \%$ and $8 \%$ more in comparison with basic SCC.

\section{Acknowledgments}

The authors are very thankful to the Vasavi College of Engineering, for permitting to utilize the resources in the concrete laboratory, also special thanks to UGC for sanction of the fund for this project.

\section{REFERENCES}

[1] Masahiro Ouchi, Makoto Hibino, Hajime Okamura, "Effect of superplasticizer on self-compatibility of fresh concrete," Transportation research record journal of the transportation research boards1574: page no:37-40,1997.

[2] CYR.M, Mouret,"Rheological characterization of superplasticizer cement paste containing mineral admixtures", Consequences on Self-Compacting Concrete Design Special Publications page no:241-256. (2003)

[3] Brouwers, H, Radix, H, "Self-compacting concrete, the theoretical and experimental study", cement and concrete research, Elsevier publications, Issue 35 Page no:2116-2136. (2005).

[4] P. Dinakar and S N Manu, "Concrete mix design for high strength self-compacting concrete using metakaolin", Journal of construction and building materials, Elsevier publications, Volume -60, Issue 3 Page no:661-668., (2010).

[5] Siddique R, "The properties of the self-compacting concrete containing the class F flyash", Material and design journal, Elsevier publications, Volume -32, Page no:1501-1507, (2011).

[6] Corinaldesi V, Moriconi, G, "Characterization of self-compacting concrete prepared with different fibers and mineral admixtures", Cement and Concrete Composites, Elsevier publications, Volume -33, Page no:585-601,(2011)

[7] Siddique R, Aggarwal P and Aggarwal Y ("Influence of water/powder ratio on strength properties of self-compacting concrete containing coal flyash and bottom ash", Journal of construction and building materials, Elsevier publications, Volume -29, Page no:73-81. 2012)

[8] Assem Hassan and Mohammed lakherim, "Effect of condensed silica fume and metakaolin on the rheology of the self-compacting concrete". IOSR Journal of structural and civil engineering, Volume-5, Issue 8, page no:318-325, (2012)

[9] Vikas Srivastava, Rakesh Khanna and Mehta P K, "Effect of condensed silica fume and metakaolin combination on the concrete", International journal of civil and structural engineering, Volume 2, issue 3, page no:895-900. (2013)

[10] Ramanathan P, Baskar I, Muthupriya. P and Venkatasubramani R, "The performance of self-compacting concrete containing different mineral admixtures", KSCE journal of civil engineering, Volume 17, Pageno:465-472, (2013).

[11] Ionnais P sfikas, Efstratios G Badiog Ionnis and Konstantin G.T, "Rheology and structural properties of the self-compacting concrete mixes containing metakaolin", Journal of Materials and construction, Elsevier publications, Volume -32, Page no:121-127. (2014)

[12] Hafez E elyamany, and. Elymoaty and Basma Mohamed, "Effect of filler type of material on physical, structural and microstructure properties of the self-compacting concrete", Journal of cement and composites, Elsevier publications, Volume -53, Page no:295-307. (2014),

[13] Akinpelu M A, Odeyemi S O, Olafusi and Muhammed FZ, "Evaluation of the splitting tensile strength and compressive strength relationship of self-compacting concrete", Journal of King Saud University-Engineering Sciences. (2017)

[14] EFNARC-2005- "European Federation of National Associations Representing for Concrete-specifications for the self-compacting concrete"

[15] ACI 237R-07-2007, "Emerging technology series on self-consolidating concrete -reported by American concrete institute revised ACI manual of concrete practice (MCP)

[16] IS:10269-2015-Bureau of Indian standards-Ordinary Portland cement-specifications-sixth edition, New Delhi, INDIA.

[17] IS:383-2016- Bureau of Indian standards-Coarse and fine aggregate for concrete-specifications- New Delhi, INDIA.

[18] ACI international seminar on High volume Flyash and Blended concrete -2001 .

[19] IS:10262-2009- Bureau of Indian standards-Guidelines for concrete mix design proportioning- New Delhi, INDIA.

[20] IS:516-reaffirmed 2004- Bureau of Indian standards-Methods of Tests for Strength of the concreteeighteenth reprint-2006-New Delhi, INDIA 